This item was submitted to Loughborough's Research Repository by the author.

Items in Figshare are protected by copyright, with all rights reserved, unless otherwise indicated.

\title{
Subtle forms of racism in strategy documents concerning Roma inclusion
}

PLEASE CITE THE PUBLISHED VERSION

PUBLISHER

Wiley

VERSION

AM (Accepted Manuscript)

\section{PUBLISHER STATEMENT}

This is the peer reviewed version of the following article: POPOVICIU, S. and TILEAGA, C., 2019. Subtle forms of racism in strategy documents concerning Roma inclusion. Journal of Community and Applied Social Psychology, 30(1), pp. 85-102, which has been published in final form at https://doi.org/10.1002/casp.2430. This article may be used for non-commercial purposes in accordance with Wiley Terms and Conditions for Use of Self-Archived Versions.

\section{LICENCE}

CC BY-NC-ND 4.0

\section{REPOSITORY RECORD}

Popoviciu, Salomea, and Cristian Tileaga. 2019. "Subtle Forms of Racism in Strategy Documents Concerning Roma Inclusion”. figshare. https://hdl.handle.net/2134/38032. 


\section{SUBTLE FORMS OF RACISM IN STRATEGY DOCUMENTS CONCERNING ROMA INCLUSION}

Salomea Popoviciu (Ruhama-UK CIC)

Cristian Tileagă (Loughborough University)

Keywords: Roma inclusion, Government strategy for Roma people, Roma crime, discursive research, frame analysis, subtle racism.

To appear in Journal of Community and Applied Social Psychology. 


\section{Abstract}

This paper explores the ways in which national governments address the social inclusion of disadvantaged and disenfranchised groups in official strategy documents of the state. Data for this study comes from a corpus of four key government strategy papers concerning Roma inclusion published by the Romanian Government between 2001 and 2015. This paper specifically looks at the ways in which strategy documents frame the problem of "crime" in the context of Roma inclusion. Texts were analysed using a critical frame analysis approach complemented by insights from discursive research. The findings highlight that although generally government policy on the Roma adopts and promotes a progressive/liberal agenda that aligns with EU strategic goals, pronounced ambivalence toward Roma people and subtle forms of racism are still present and persist. 


\section{Introduction}

Attitudes and practices toward Roma people in Europe span a very diverse range of shades and nuances - from tolerance and compassion to eliminationism (Tileagă, 2015). Research shows that many Roma people experience prejudice and discrimination in their daily interactions with non-Roma people, including, but not limited to, city councillors, bank customer advisers, insurance sales agents, suppliers, retailers, and customers (Anttonen, 2008; Lasticova \& Findor, 2016; Varadi, 2014). This reflects the ambivalent status of the Roma people in Europe: on the one hand, Roma are romanticized, while, on the other hand, vilified for exploiting the welfare system and exhibiting violent and criminal behaviours (Tileagă, 2007, 2015; Villano, Fontanella, \& Di Donato, 2017; Zamfir \& Zamfir, 1993).

According to the European Court of Auditors (2016), Roma are the largest European ethnic minority, with an estimated 6.2 million Roma people living in member states, the majority in marginalized and disadvantaged communities. Roma people are among the most disadvantaged of European citizens. Many continue to face substantial discrimination in education, employment, health and housing (European Commission, 2018).

In Europe, Romania has one of the highest numbers of Roma people, who comprise $3.3 \%$ of the population $(621,573)$ (Institutul National de Statistica, 2011). The disparities between Roma and non-Roma people are significant. For example, according to available data approximately $34 \%$ of Roma are illiterate and have no formal education, compared to $5 \%$ of the non-Roma population (United Nations Development Programme, 2012). Also, $66 \%$ of non-Roma men and $53 \%$ of non-Roma women aged between 15 and 65 are employed, whereas for Roma people the employment figures are $42 \%$ for men and $19 \%$ for women. Moreover, most Roma people work in undeclared or black economy work (World Bank, 2014). Only about half of Roma have access to healthcare, in comparison to $97 \%$ of non-Roma (Tarnovschi, 2012). More than $90 \%$ of Roma own houses that do not have access 
to utilities such as hot water, central heating or connection to sewage (Duminica \& Ivasiuc, 2013).

Since 2011, the European Commission has allocated approximately $€ 1.5$ billion for the inclusion of marginalized communities, including Roma, as part of its 2014-2020 strategic programme (European Court of Auditors, 2016). Even if some progress has been made, Roma people continue to be disadvantaged, and are often stereotyped as culturally inclined towards crime and threat to public safety (Hammarberg, 2018).

In this paper, we consider how national governments (in this case the Romanian government) address some of the challenges arising from Roma inclusion strategies. We specifically look at how "crime" is framed in official documents outlining government strategy. According to data collected by the European Union Agency for Fundamental Rights (2012) policy responses to crimes in the context of Roma inclusion are primarily focused on racist crimes, or anti-Roma prejudice. These policy responses differ widely in EU member states. For example, there are only four member states (Czech Republic, Netherlands, Poland and Sweden) that record and publish data on anti-Roma crimes, leaving a majority of states that due to limited means of data collection - are failing to tackle anti-Roma prejudice. A recent Fundamental Rights Report (2017) shows that one out of five Roma people reported that in the 12 months preceding the study experienced hate-crime or were subject to hatespeech due to their Roma background. Although the European Commission called on Member states to address the problem of anti-Roma crimes in their national strategies for Roma inclusion, strategies in as many as twenty states do not include any special mention or discussion of issues related to crime. 
In Romanian strategy documents for Roma inclusion, there are two main categories of solutions proposed. The first category of solutions focuses on individual development in the form of counselling or employability skills training that aim to help Roma people integrate into mainstream society. The second category concentrates on systemic changes such as structural reforms in education, employment, health and housing in order to formally enable the full participation of Roma people - especially those living in disadvantaged and segregated communities - to economic, social, cultural and political life.

In this paper, we focus on how individual and systemic solutions are being mobilized and discussed in Romanian strategy documents that are designed to advance and promote social inclusion. We consider how references to crime in the context of tackling Roma inclusion are made, and the ways in which subtle racism is a pernicious consequence of their uncritical use.

\subsection{Public policies for redressing ethnic disparities and subtle forms of racism}

In social psychological theories about subtle forms of racism there is a general consensus that there are two opposing trends concerning public policies that address social disparities based on gender, race or ethnicity ${ }^{1}$. On the one hand, there are progressive trends that push for systemic solutions for inequality. On the other hand, there are other kinds of trends that oppose these solutions. Theories proposed by social psychologists to account for white opposition to affirmative action measures for racial minorities arose out of a concern to explain the paradoxical trends concerning (white) public opinion, especially in the United States. For example, surveys in the 1970s found that there was a widespread opposition reported by white Americans to affirmative policy measures designed to help racial minorities (Pettigrew, 1975). However, there was also a decline in support for discriminatory policies, which were becoming illegal, such as school or neighbourhood segregation or laws banning interracial marriage. During the same time period, there was a consistent change in 
the content of self-reported racial attitudes expressed by white people (Bobo, Charles, Krysan, \& Simmons, 2012). Common explanations for social and economic disparities shifted from inborn failings of black people towards cultural attributions. For instance, white people were arguing that black people might be less "industrious" or more "lazy", and thus, not displaying the American valued traits of hard work, motivation, perseverance, and industriousness. Likewise, the thrust of prejudices seemed to shift from generalized attributions based on biological differences in appearance, to those based on cultural characteristics ${ }^{2}$.

To a number of social psychologists it looked as if white people continued to experience anti-black affect, while also embracing the principles of racial equality and inclusion in areas such as education, employment, housing, segregation and interracial marriage. Thus, existing disparities between racial groups were beginning to be discussed by some authors in terms of subtle forms of prejudice. Four different concepts were proposed, all of which linked ethnic/racial disparities with subtle forms of prejudice: symbolic racism (Sears, 1988), modern racism (McConahay, 1986), ambivalent racism (Katz, 1981) and aversive racism (Dovidio \& Gaertner, 1989, 1999, 2000).

Firstly, according to the theory of symbolic racism (Sears, 1988), black people were no longer seen as the victims of a Jim Crow variety of prejudice and discrimination ${ }^{3}$. However, white opposition to affirmative action programs designed to help racial minorities was deemed an expression of indirect prejudice. Symbolic racism, as the more acceptable expression of social and cultural norms, supplants the unacceptable, biological racism. As Kinder and Sanders argue, "prejudice is expressed in the language of American individualism" (Kinder \& Sanders, 1996, p. 106).

Secondly, McConahay's (1986) notion of "modern racism" is based on similar assumptions. This new variety of racism is expressed in covert ways and avoids direct 
appeals to racial values. The conflict that facilitates the expression of "modern racism" is a conflict between liberal values and anti-black sentiments. "Modern racists" do not endorse, nor do they advocate extreme negative stereotypes; yet they promote a practice of resistance to change in the name of historical American values. Consequently, any perceived failure to progress on the part of black people was understood to be a result of their unwillingness to work hard, thus violating traditional American values such as self-reliance, work ethic, obedience, individualism and discipline - rather than the effects of prejudice or discrimination. Policy demands for resolving racial disparities such as special housing assistance, affirmative action in university admissions and busing for racial integration were considered excessive. Affirmative action was seen as a way of offering black people more than they deserved.

Thirdly, the notion of "ambivalent racism" maintained that white people can experience emotional conflict between positive and negative feelings (Katz, 1981). For example, white Americans may feel appreciative of Black minority success, but, may, at the same time, display paternalistic attitudes towards successful black people and feel resentful towards underprivileged black individuals, who may appear to them as unwilling to work hard enough. In addition, pro-black attitudes attribute black disadvantage to discrimination and a lack of opportunities, whereas anti-black attitudes attribute black disadvantage to unambitious, disorganized, and un-American work values (Fiske, 2012). Similarly, research on the attitudes of Italian majority towards Roma showed that Roma people were ambivalently perceived (Villano, Fontanella, \& Di Donato, 2017). Majoritarian attitudes could flip from one pole to another, often depending on situational cues.

Lastly, Gaertner and Dovidio (1986) used the concept of aversive racism to explain the ways in which liberal white Americans can endorse egalitarian values and deny personal prejudice but discriminate in practice by finding post-hoc reasons that justify their 
behaviours. For example, in situations such as employment or university admissions, white people could rationalize their decisions of consistently choosing a white candidate over a black candidate when the credentials were evenly matched, on factors other than race (Dovidio \& Gaertner, 1989).

The various notions designed to capture the particularities and subtleties of a changing "racism" are arguably describing a historical and cultural shift from the unambiguous use and declarations of adhesion to racial values to qualified denials of prejudice in societies that place different types of legal and institutional controls on direct, hostile, expressions of prejudice. The human types described by modern, symbolic and ambivalent forms of racism can blame minorities for their predicament, and, in doing so, they reproduce an ideology where "widespread acceptance of the principles of equality, integration, and antidiscrimination is offset by widespread resistance to their concrete implementation." (Dixon et al., 2012, p. 12).

Other studies took up and developed commentaries and analyses of this historical and cultural shift in the expression of prejudice. For example, Van Dijk (1992) used discourse analysis to look at the ways in which white ethnic majority people in the Netherlands thought and wrote about ethnic and racial inequalities. Van Dijk found that it was common for people to deny being racist, while still being committed to a way of talking that was helping sustain disparities between groups regarding access to institutions and services such as education, employment, health and housing. Public mainstream political and academic discourse in Western European nations has moved away from portrayals of ethnic or racial groups as "inferior" due to some essential quality, to explanations in terms of cultural differences. Also, in their analysis of new forms of racism in France, Balibar \& Wallerstein (1991) proposed that a racism without race emerged in the 1970 s debates about migration and multiculturalism. A differentialist neo-racism (Taguieff, 2005) tended to focus on cultural 
differences and although respectful in discourse, it preserved racial and ethnic differences. Portrayals of minority cultures and peoples as "social problems", "deviant", or not "culturally assimilable" continues to be a discernible feature of those discourses (Balibar \& Wallerstein, van Dijk, 1993; Taguieff, 2005, Tileagă, 2005).

In the UK, Reeves (1983) documented “deracialization” as a strategy used by British politicians to support immigration restrictions. Talk about minorities was exclusionary, although the language used was not commonly associated with racism. For example, the category of "nation" began to increasingly replace "race" in order to warrant claims about defending national borders from migrants and refugees. Perceived cultural or racial differences were (and are) frequently used to blame the victims for the systemic problems that societies were facing, and thus "justifying inequality by finding defects in the victims of inequality" (Ryan, 1971, p. xiii).

In the United States, values traditionally associated with political conservatism (Sniderman \& Tetlock, 1986) or the protestant work ethic (Kinder \& Sears, 1981) were used by some people belonging to the dominant majority to oppose governmental policies which were aimed at redressing social and economic disparities in outcomes within American society. According to a number of academics, disadvantage was invariably construed as an outcome of an individual's attitudes toward discipline and hard work, which were perceived as specific to some cultures, races, or ethnicities, rather than the outcome of systemic inequality (Augoustinos, Tuffin, \& Every, 2005; Kinder \& Sanders, 1996; Mendelberg, 2001). Opposition to public policies for disadvantaged groups such as affirmative action programs can be supported by recruiting liberal principles, such as individualism, meritocracy, egalitarianism and fairness, rather than in terms of race. Thus, group dominance is being reproduced, less in terms of theories of racial superiority, but more as a manifestation of a system of discrimination which includes practices of control, oppression, marginalization 
and exclusion, whilst overt prejudices are publicly denied (Katz \& Taylor, 1988). As Billig (1996) convincingly argued, modern prejudices are "justified in terms of any value but a racial one" (p. 248).

Other social scientists argue that the social practices which maintain disparities between racial or ethnic groups are the result of historical systems of inequality (Wetherell \& Potter, 1992). Approaches to subtle forms of racism theorize a conflict between individual, psychological motives/propensities and socially acceptable expressions. Discourse analyses of subtle racism focus on actual rhetorical practices that reproduce inequality in liberal, egalitarian, and progressive societies. As Wetherell and Potter have put it, "the conflict is not (...) between psychological drives and socially acceptable expressions (...) but between competing frameworks for articulating social, political and ethical questions" (1992, p. 197) ${ }^{4}$. Therefore, it becomes important to understand the nature of, and the uses to which, these competing frameworks can be put, how they are mobilized in everyday, as well as official, discourse, and the kinds of ethical and moral questions and quandaries they bring about.

It has been argued that distinctions between old and new forms of racism are sometimes overplayed or overstated in the literature (Leach, 2005). When one turns to the intricate nature of the Roma predicament in Europe one begins to appreciate that the distinction between old and new forms of racism may not neatly map onto the content and form of elite frameworks designed to maintain disadvantage and the status quo. As Okely argues, "the threat which the Gypsies, as a minority, appear to represent to the larger society is largely ideological." (1983, p. 213). They defy the dominant societal systems of education, labour and employment. This leads nation-states to attempt to manage them through policies that embed to various degrees "condescension and impatience, (...) paternalism and 
despotism, (...) benevolent inactivity and strenuous attempts at radical solutions" (Fraser, 1992, p. 277).

We focus on "crime" as an enduring dimension of a stereotypical portrayal of Roma people with roots in social expectations, and symbolic imagery around deviance and marginality (Villano, Fontanella, \& Di Donato, 2017, Zamfir \& Zamfir, 1993). We are not looking at crime in terms of a purely stereotypical description that crops up here and there but, rather, we are concerned with how (Roma) "crime" functions as a trope in elite texts, narratives, about social issues and social problems. We contend, following Allport, that "stereotypes ... play an important part in prejudice, but are not the whole story" (1954, p. 189). Stereotypes, especially cultural stereotypes, take a variety of forms, and are not always, and necessarily, related to direct negative evaluations.

Using the case of the Roma people, and the ways in which the problem of crime is presented in Romanian strategy documents for Roma inclusion, we show that racist beliefs and assumptions, especially when "detached from their old value", insidiously, yet unthinkingly, manifest themselves "under the protection of acceptable, and formerly contrary, values" (Billig, 1996, p. 247). We argue that elite frameworks or ideologies that underpin the promotion of strategic policies for disadvantaged and disenfranchised groups are sometimes perfectly adapted to, and at the same time reproduce what Allport has called "the prevailing temper of prejudice" (1954, p. 204) in a given society. 


\section{Context of research}

The first document of the Romanian state to acknowledge a difference in living standards between Roma and non-Roma people was a strategy document published by the Communist Party in 1978, titled "Communication concerning some problems raised by the Gypsy population for our country" (Partidul Comunist Roman, 1978). The document was authored by a consortium of public authorities that collectively labelled Roma people as "unstable" (p. 5), "backward" (p. 5), "parasites" (p. 6), the cause of "mass spreading of diseases" (p. 4), and "responsible for the majority of recorded crimes" (p. 5) (The National Commission for Demographics, 1977). The document used overtly racist language to describe the way of life of Roma people, and it included provisions for assimilation policies in the areas of education, health, employment, housing, and social participation. At this time, the political rights of Roma people as members of an ethnic minority were not acknowledged. The political plan was to "help" Roma people to become people indistinguishable from the majority of ethnic Romanians.

After the 1989 Romanian Revolution, the Organization for Security and Cooperation in Europe began to draw international attention to some of the problems faced by most Roma people. An Office for Democratic Institutions and Human Rights was opened, and within this office, a Contact Point on Roma and Sinti ${ }^{6}$ Issues was established in Warsaw (Cace, Neagu, Rat, \& Ivasiuc, 2014). The Contact Point was led by Roma academics who tried to mobilize European institutions that could put pressure on the Romanian Government so that it would begin to address the anti-Roma crimes committed post-1989. As a result of awareness raising efforts by human rights activists, in 1993, the European Commission proposed a set of recommendations for the improvement of the situation of Roma people. However, there were no immediate legislative changes in Romania. It was only after 1997, when the European Commission answered Romania's request to join the EU on the condition that the 
government would show progress in "improving the Roma situation", that political changes began to be made. The first Governmental Strategy for the Improvement of the Situation of Roma was published in 2001 (Guvernul Romaniei - HG 430/2001, 2001). Also, in the same year, the National Agency for the Roma was established - the first of its kind in Romania. In 2002, the European Commission set forth a more detailed set of conditions for policies concerning the improvement of Roma situation. These conditions were introduced in the new national plan (2006-2008) of the first Governmental Strategy.

In 2011, some of the results of the Governmental strategy for the improvement of the situation of Roma people were presented during the international conference held under the patronage of the European Parliament, "National Roma Strategies: Ensuring a Comprehensive and Effective European Approach". The overall consensus of academics and policymakers was that the commonly agreed targets for social inclusion were not met. Among the barriers to meeting agreed targets were bureaucracy, and an overly complex process of biding for and accessing European funds (European Commission, 2011). Consequently, the European Commission proposed the adoption of a stricter monitoring policy of national strategies for Roma inclusion. In the same year, the European Framework for the National Roma Inclusion Strategies was created for the Europe 2020 programme. This development ensured that the European Commission would not only make recommendations for each EU member state but would also monitor progress. Romania's response was to draft another National Strategy, this time concerned with the "Inclusion of Romanian Citizens belonging to Roma minority 2012-2020” (Guvernul Romaniei - HG 1.221/2011, 2012). By the end of 2012, the European Commission conducted evaluations of the national strategies of all member states, and created the European Platform for Roma Inclusion with the aim of facilitating a common framework for European member states for the social inclusion of Roma people. Consequently, the 2012 Romanian Governmental Strategy was withdrawn and 
a new Romanian Governmental Strategy for the Inclusion of Romanian Citizens belonging to Roma minority for the period of 2014-2020 was drafted and adopted (Guvernul Romaniei HG 18/2015, 2015).

From 2001 to 2015, each new Governmental strategy for Roma people was drafted in line with the latest EU requirements for EU membership. All of the Governmental Strategies were built on a general political consensus of the existence of economic, social and political disparities between Roma and non-Roma people. Also, each strategy was authored by multiethnic representatives of various Ministries and organizations, which collectively produced four documents which proposed systemic, political solutions for the inclusion of Roma people in Romanian society. The aim of the present analysis is to look at how "crime" is framed in these four official documents outlining government strategy for Roma inclusion.

\section{Method}

\subsection{Data}

This paper is based on data collected for a larger project that aimed to explore the views expressed by social workers and other professionals about ethnic disparities in what is usually seen as an anti-racist context where public policies that address disparities are proposed. The data corpus for this paper was comprised of the four public strategy papers concerning Roma inclusion in Romania adopted by the Romanian Government, between 2001 and 2015. The four documents were:

1. The Governmental strategy for the improvement of Roma situation (2001) - adopted by the Romanian Government in 2001, with a plan for 2001-2004 (Guvernul Romaniei, HG 430/2001). 
2. The Governmental strategy for the improvement of Roma situation (2006) - adopted in 2006 with a plan for 2006-2008 (Guvernul Romaniei, HG 522/2006, 2006). For 2008-2010 the Government did not propose an additional plan for Roma inclusion.

3. The Governmental Strategy for the inclusion of Romanian citizens belonging to the Roma minority for the period of 2012-2020 - adopted in 2011 (Guvernul Romaniei, HG $1.221 / 2011)$ and repealed in 2015.

4. The Governmental Strategy for the inclusion of Romanian citizens belonging to the Roma minority for the period of 2015-2020 (Guvernul Romaniei, HG 18/2015). This strategy was published in 2016, although its action plan included the year 2015. Due to the fact that the fourth strategy was adopted by the Government before the third strategy's action plans expired, there is a time overlap between the two documents. Table 1 provides an overview of the length of these documents.

\section{[insert Table 1 here]}

\subsection{Analytic approach}

Texts were analysed using frame analysis complemented by insights from discursive research. We turned to a version of frame analysis that has been used for policy evaluation (Verloo, 2005, 2007) and in studies about some of the ways in which public opposition to policy measures for redressing ethnic or racial disparities may be reduced (Gandy, Kopp, Hands, Frazer, \& Phillips, 1997; Gilliam, 2006, Iyengar, 2005). Coding of raw text was based on techniques and principles outlined by Verloo (2007) for frame analysis. Questions guiding the coding were around "problem", "causality", "voice" and "solutions". Problem was defined as a situation regarded by policymakers as troublesome or harmful and requiring a solution. Problem included (a) what was seen as a problem, (b) who was seen as a problem, (c) why and how it was portrayed as a problem, (d) who portrayed it as a problem (voices). 
Causality related to who or what was seen to (a) have made the problem, (b) have the problem, (c) be responsible for sustaining the problem, (d) solve the problem, (e) not be a problem, and (f) be the normative group. Voice was defined as a descriptive or distinctive name, title or designation belonging to a person, study or a political document used to confer preference or rejection of an argumentative position vis-à-vis the problems and the possible solutions concerning ethnic disparities. Solutions referred to the courses of action about (a) what can or should be done, (b) the priorities, (c) resources, (d) target group and (e) voices proposing the solutions.

Publications were initially openly coded, with coding labels taken directly from the language of the texts. Frame analysis was used to code different means of discursive positioning in each text. During the open coding stage, policy documents were analytically broken down into separate blocks, which ranged from a few lines of text to a few pages, and coded using in-vivo codes. A succession of codes were developed and these codes were used as indicators that related directly to the data. In-vivo codes had a provisional character, and in the course of analysis became increasingly numerous, differentiated and abstract. Theoretical codes, in the sense of concepts adopted from scientific theories were later added, and replaced some of the provisional in-vivo codes, as the researchers' theoretical background knowledge offered additional tools which helped guide the interpretation of the texts.

The framing techniques helped group ideas into frames, defined as organizing principles used to transform flexible and fragmentary information into a relatively meaningful narrative including the definition of a problem and (usually) a proposal for a solution (Verloo, 2005). Frames were identified in relation to a specific issue. For example, in all strategy documents the broader issue of Roma "character" and/or way of being in the world was presented as a policing problem, an educational problem or a policy problem. These three different approaches, involving one issue (Roma character) suggested three 
different frames. For instance, mentions or suggestions that problems associated with the Roma "character" could be solved through education denoted an educational frame; proposals for policy solutions for problems associated with the Roma "character" denoted a policy frame, and so on.

Frame analysis provided a useful means of sifting through and organizing the data in meaningful chunks. However, we felt that, in order to capture the full complexity of the strategy documents, we needed to also attend to the situated discursive and textual practices. Frame analysis, which was introduced by Goffman (1974), and developed by social movement theorists (e.g., Snow, Rochford, Worden, \& Denford, 1986), can be applied to a virtually unlimited number of topics (Kuypers \& D'Angelo, 2010), and there are multiple ways of doing frame analysis. Verloo's (2005) methodology, which we drew upon, proposes the use of a separate, systematic summary of the data called a "supertext". This "supertext" is a secondary document comprised of the researchers' perceptions about the problem, causality, voice and solutions displayed in the original documents. The coding of frames, in Verloo's research, was done on the supertext. Our coding was performed on the original text. In addition, we also wanted our analysis to focus on how government texts were put together and how they communicated and constructed narratives related to "problems" and "solutions". In this study the policy texts analysed were seen primarily as a resource in communicating and constructing social and cultural meaning related to solving social problems.

There are a variety of ways of doing discursive research - and multiple developments such as conversation analysis (e.g. Sacks, Schegloff, \& Jefferson, 1974; Sacks, 1984), discursive psychology (Potter \& Edwards, 2001), or discourse analysis (Potter \& Wetherell (1987). The common thread linking these approaches is a view of language embedded in social interaction. One of the main aims of discursive research is to explore how matters such 
as prejudice or racism are built up through descriptions of actions, events or circumstances (Hepburn \& Wiggins, 2007). The novel proposition in discursive research - which we adopted in this study - was that what people say, or write, does not necessarily represent what they are "really" thinking, or even what is "really" happening. For discursive analysts, talk and text are seen primarily as a resource in communication (Augoustinos \& Every, 2007; Figgou \& Condor, 2006; Tileagă \& Stokoe, 2015). Discourse analysis has been applied as a stand-alone approach successfully to the analysis of texts produced for a variety of purposes (e.g., Tileagă, 2009, 2012).

\section{Analysis}

Firstly, and more generally, frame analysis complemented by discursive analysis showed that a pervasive feature of all of the strategy documents for Roma inclusion were proposals for the individual development of Roma people. These proposals for individual development were accomplished discursively via a series of terms designed to advance transformative-inducing actions (cf. Austin, 1961). Strategy proposals were intended to "educate", "counsel", “intervene", "fight" or "prevent" an identifiable negative aspect of individual Roma character and behaviour. A disposition of Roma people toward problematic behaviours was implied through a recurring association between ethnicity and undesirable behaviours. For example, programs were suggested to educate or counsel Roma people about illegal behaviours: the dangers of early marriage (2001, 2015), justice and public order (2001, 2006, 2011, 2015), and school enrolment of children (2001, 2006, 2011, 2015). There were also preventive programs proposed for behaviours such as: working in the black market economy (2001), family violence (2015), catching or spreading sexually transmitted diseases (2001, 2011, 2015), child abuse and neglect (2001, 2011, 2015), and engaging in crime (2001, 2011, 2015). Although it was implied that some of these preventive and educational measures will 
have a positive effect, the strategy documents were also, uncritically, associating ethnicity with problematic behaviours.

Secondly, and more specifically, we identified clear 'framing' techniques used to associate Roma traits with crime and illegal behaviours. In total, we documented eleven instances across the four strategy documents where Roma ethnicity was associated with crime. Not surprisingly, most were found under the heading of "Justice and Public Order". In this paper, we discuss four typical examples of these associations. Mentions of anti-Roma crimes, anti-Roma violence or anti-Roma prejudice were not found in the documents. An association between Roma character and crime was accomplished using three types of frames: (1) policing frame, (2) policy frame, and (3) educational frame. The latest governmental strategy published in 2015 is the only document not to make any explicit links between Roma ethnicity and crime. However, as our analysis revealed, the association was still present, albeit indirect.

\subsection{Policing frame}

Extract 1 presents an example of the policing frame from Strategy 1a (2001). The text appeared under the heading "Justice and Public Order". The bulk of each strategy was apportioned into either stand-alone numbered, lettered, or bullet-point paragraphs, divided into categories and placed into tables. For example, under the heading "Justice and Public Order", in the 2001 document, there are twelve relatively concise and numbered interventions, similar in appearance to the numbered articles found in most legislative documents. Paragraph number 72 presents the last planned intervention of this section.

Extract 1: Policing Frame for fighting and preventing Roma crime (HG 430/2001 Original in Romanian) 
1 72. Developing a partnership relationship and organizing

2 monthly meetings with the local police and Roma community

3 leaders, in order to prevent and fight crime among citizens of

4 Roma ethnicity.

The language used in Extract 1 to state that Roma people have a "crime" problem that needs prevention and intervention measures (line 3), contains an "essence attribution" (cf. Anthias, 1998). In fact, by placing the text under the heading of "Justice and Public Order" the notion of Roma ethnicity is constructed as problematic. This may both reflect and perpetuate a system of dominance-subordination (Condor, 1988), a situation in which only the majority group has the power to decide what is lawful and what is unlawful.

The categories of "citizens of Roma ethnicity" (lines 3, 4) and "Roma community leaders" suggest that the text attends to multiple layers and moral descriptions of ethnicity. By using a subtle categorization of people, a moral hierarchy is proposed. On the one hand, "citizens of Roma ethnicity" - as a general category of people - are pictured as a separate, and problematic, community. The category "citizens" construes the problem, as well as the solution, as a matter of civic, public, concern. As Tileagă (2009) has shown, construing 'problems' as a matter of public, rather than individual concern, is a way of fending off potential criticism, as well as a way of providing a "generic warrant" (Lynch \& Bogen, 1996) for future courses of action. It also makes government intervention reasonable, and justified, by virtue of being an intervention on people who should be upholding the values of that very government. Roma people were described as either criminal (thus the need to "fight" existing crime) or prone to crime (thus the need to "prevent" crime). Consequently, the potentially problematic nature of state solutions does not need to be directly justified. On the other hand, a small subgroup of Roma people ("community leaders") was placed on a morally superior ground compared to the general group of Roma people. This elevated group of leaders is yet 
still depicted as "different" compared to the non-Roma local police. The idea of a solution depending on a partnership between Government officials, the local police and Roma leaders implies an ordering of power, dominance, influence and responsibility in solving a Roma crime problem.

There was also an implied understanding of Roma particularities that needed a longterm effort to change, an understanding which places Roma people beyond a moral boundary that applies to majority groups (Tileagă, 2007). According to governmental strategies, an improvement in Roma behaviours presupposes a continuous monthly intervention. In the table where the proposed measure presented in Extract 1 was placed within the strategy text, there was a deadline column. For other types of measures such as housing projects, health programs, or educational policies, deadlines usually consisted of a particular calendar date. However, fighting Roma crime had the word "permanent" attached to it in the deadline column, suggesting that Roma crime is a perennial problem.

The text implied that there was a problem with Roma crime, but at the same time it was also careful to frame the initiative for solutions as a partnership (line 1), pointing to the inherent ambivalence (cf. Marinho \& Billig, 2013) present within the strategy document. Roma ethnicity was associated with a deficient character, notions of chaos, crime and impending social disorder. Nonetheless, the proposals for Roma crime prevention were textually found alongside the other proposals which focused on improving the status and standing of Roma people in Romanian society (i.e. under headings such as: Housing, Health, Education, etc.). Whereas the set of measures related to housing, health, education, were focused on the betterment of the situation of Roma people, the policing concerns were rehearsing uncritically demeaning stereotypes and hackneyed prejudices. The absence of any reference to anti-Roma prejudice or hate crimes against Roma people, make this framing of the "problem" of crime even more disturbing. 


\subsection{Policy Frame}

In the strategy document published in 2011, the association between Roma and crime was re-framed in a subtler way. The text presented in Extract 2 - which used a policy frame, appearing under the heading "Priorities, Politics, Existing Legal Framework" - began with a relatively lengthy introduction about the aims of the Governance Programme for 2009-2012.

\section{Extract 2: Policy frame for (Crime) prevention among Roma people - (HG 1.221/2011 - Original in Romanian)}

1 According to the Programme for Governance for the period of 2 2009-2012, the problem of Roma social inclusion is found in

3 the strategies of the relevant Ministries and contains 4 measures for Roma in the domains: education, employment, 5 health, and housing. According to this [document] "the problem 6 associated with the Roma community is a special domain that 7 necessitates both local level efforts, and a correlation with 8 the European efforts of eliminating social discrepancies. It 9 is considered necessary for the National strategy to be 10 applied in a more efficient manner and a reorientation of this 11 strategy towards specific programs, designed to assure a 12 substantial improvement of Roma situation, through: -consolidating the implementation structures for the national strategy for Roma at a local level; -realizing a viable partnership between the public 16 administration structures and Roma communities; 
-resolving property problems regarding the lands and housing

18 held by Roma and implementing some housing rehabilitation

programs in areas in which Roma live, through assuring access

to electricity, drinking water, sewage, natural gas,

sanitation;

27

-making efficient the measures which target sectorial aspects (access to the job market, promoting income generating activities, access to medical services, reducing school dropout, promoting artistic values, creation of civic education programs and crime prevention)"

Quoting directly from the original Governance Programme, the text was presented as a document concerned with systemic Roma problems requiring systemic policy-based programs for Roma inclusion. The text mentioned consolidating structures (line 13), administrative partnerships (line 16), access to safe housing, improved infrastructure in disadvantaged Roma communities (lines 17-21), and access to employment, health and education (lines 23-25).

Within this policy frame, there was a display of a progressive ideology as evidenced by the proposals of compensatory policies directed towards the redistribution of welfare for disadvantaged groups (Duncan, 1977). However, seemingly disconnected from the other systemic proposals in the same text, almost an after-thought, the text introduces "civic education" and "crime prevention" (lines 25-26), measures that stand in stark contrast with the compensatory thrust implied by the other proposed measures. The text seems to imply that measures designed to facilitate access to employment, health and education, and the promotion of Roma "artistic values" are not enough to make sectorial measures efficient (line 
22). It seems to imply that the stakes related to Roma inclusion are high, and not only contingent on compensatory policies. What is different to previous strategy documents is that, in this instance, the target group is not explicitly mentioned. What is perhaps unambiguous is that the text does not refer to (hate) crime prevention toward Roma people but rather implies, as previous strategy documents have done, that Roma crime continues to be a problem.

The crime prevention measure from the 2011 Strategy was expressed in fewer words compared to the similar ones found in the 2001 and 2006 Strategies. It was mentioned as one measure alongside a string of other measures. Also, and more interestingly perhaps, it was the only "crime prevention" measure mentioned in the entire document, which was not given its own stand-alone numbered paragraph. It could be argued that the 2011 strategy document is perhaps more actively concerned with fending off possible future criticism by embedding a controversial measure from previous years alongside more acceptable, progressive, policies. The association between Roma ethnicity and crime is nonetheless still very much a concern in the text, pointing perhaps to the persistence of a cultural theory about psychologically and behaviourally "different” and in-need-of-reform Roma.

\subsection{Educational Frame}

In Strategy $1 b$ (2006), the link between Roma and crime was also made in an indirect manner, especially compared to the text from Extract 1 . Crime prevention was framed not as an issue of policing but as an educational problem. Extract 3 presents the eighth measure from a list of twelve numbered interventions proposed under the heading of "Justice and Public Order". The text follows a proposal for family, community or inter-ethnic conflict resolution strategies, and is one of a series of suggested measures:

Extract 3: Educational Frame for preventing crime (HG 522/2006 - Original in Romanian) 
The authors of the strategy document propose an educational program and the distribution of publications designed to improve social justice outcomes. The "education" component of the national crime prevention program is ambiguous. It is never made clear what "civic education" actually means. As in previous strategy documents the focus is firmly on "prevention", although it is unclear what the problem is and why is prevention needed in the first place. Ambiguous reference to "prevention pamphlets", "brochures", "leaflets" as educational "publications", but without any reference to content or focus, do not add much substance to what is presented as a "national crime prevention program".

However, differently than the text from Extract 1, and similar to Extract 2, in Extract 3, the association between ethnicity and crime was vague, allowing for multiple interpretations about which group was seen as the initiator of crime and which group was seen as the victim of crime. "Crime prevention" was explicitly associated with "members of Roma ethnicity", "Roma people", "Roma population" or "citizens belonging to Roma ethnicity" in 5 out of the 11 instances where crime prevention was mentioned in the four documents, suggesting that in this case, Roma-induced crime was at least one of the possible prevention targets. The text also allows for the possibility of anti-Roma crime prevention strategies - a topic extensively covered in academic literature (European Roma Rights Centre, 2001; Nicolae, 2006). Nonetheless, the strategy document reproduces a commonsense understanding of Roma people with little, to no knowledge of legal and civic matters, pointing to an understanding of Roma people as a problem to be solved by direct intervention. 
The text displays, but is also careful to conceal, a stereotypical understanding of Roma people as (inherently) criminal. On the one hand, Roma criminality is implied. On the other hand, a selected group of (morally-minded) members of Roma ethnicity are exempt from an association with crime, being co-selected in the group of educators and preventers of possible Roma crime. The displayed understanding of group variability does not, however, disconfirm the general stereotype about unlawful Roma. Instead, with the help of superordinate stereotypes (Maurer, Park, \& Rothbart, 1995), two opposing categories of Roma people are formed: one, in need of moral transformation and advancement, and the other, the educator, who, in collaboration with non-Roma people, can bring about that change. Nonetheless, both Roma categories of people are passive recipients of - rather than active participants in - state intervention. By carefully categorising, and distinguishing, between different categories of Roma, the text establishes the reasonableness of the proposed initiative against a potential reading of ethnic scapegoating.

Extract 3 provides a textual illustration of what Allport (1954) called re-fencing. The government text shows that it is willing to acknowledge exceptions, yet ensures, as Allport argued, that "the field is hastily fenced in again and not allowed to remain dangerously open" (p. 23). What this means is that implicit presuppositions of Roma people as "criminally Other" survive and are further reproduced. The exception only confirms the rule.

\subsubsection{Concealed association of "Roma" and "Crime"}

In the 2015 document, the association is even more difficult to spot. For starters, the word "crime" was absent from the entire strategy document. If one were to read only the document published in 2015 for Roma inclusion, one could reasonably conclude that any number of things could be prevented, "Roma crime" not necessarily being one of them. Extract 4 presents an example of how the association between Roma ethnicity and crime was 
concealed within the educational frame of the 2015 document. The text was the fourth measure in a list of five proposals found under the heading "Justice and public order".

\section{Extract 4: Educational Frame for (crime) prevention among Roma people (HG 18/2015}

\section{- Original in Romanian)}

d. Presenting a national prevention program and civic Roma minority.

The text quoted in Extract 4 appeared three times in Strategy 3, with almost the exact same wording. The only difference was the labelling of Roma people. Twice, the collaboration proposed was to be with "members of Roma minority" and once, as seen in Extract 4, with Romanian citizens belonging to Roma minority (lines 2, 3). Other than that, the reader of the latest governmental Strategy is informed about the need for civic education, presumably for Roma people possibly living in segregated Roma communities. The text from this strategy document, was placed under the heading "Justice and Public Order" suggesting a stereotypical association between Roma ethnicity and issues pertaining to law and order. Moreover, the text was worded almost exactly as the first part of the one from the 2006 document (Extract 3), with two exceptions. Firstly, the 2006 document categorized Roma people as "members of Roma ethnicity", while the 2015 document used the label "Romanian citizens belonging to Roma minority". Secondly, in the 2015 document the word "crime" was avoided. The 2015 strategy document is perhaps more a reflection of a change in the government and public discourse about Roma people. Explicit associations of "crime" and "Roma" were slowly being abandoned in official documents of the Romanian state. In other words, strategy documents were rhetorically constructed to carefully avoid the explicit association, while not (yet) completely deleting the implication. 


\section{Discussion}

In this paper we considered four key government strategy documents concerning Roma inclusion and redressing ethnic disparities published by the Romanian Government between 2001 and 2015. Our analysis has highlighted that although, generally, government strategy on the Roma adopts, and promotes, a progressive/liberal agenda that aligns with EU strategic goals, pronounced ambivalence toward Roma people, and subtle forms of racism, are still present and persist.

The findings of this paper question the utility of an all-encompassing account about tolerant views versus symbolic or modern forms of racism. The strategy documents analysed showed an overall active preoccupation for furthering strategic policies for redressing disparities between Roma and non-Roma people living in Romania. However, the same documents uncritically reproduced problematic assumptions about Roma people and criminal behaviour. Subtle forms of racism do not merely stem from opposition to public policies for disadvantaged groups (Akrami, Ekehammer, \& Araya, 2000; Barker, 1981; McConahay, Hardee, \& Batts, 1981; McConahay, 1986; Pettigrew \& Meertens, 1995; Pettigrew \& Meertens, 2001). Active, well-intentioned, proposals and programs for social inclusion and implementation of public policies for disadvantaged groups incorporate and recycle uncritically existing discriminatory and denigrating repertoires about Roma people, especially those that associate criminal behaviour with being Roma. In line with other studies (Balibar \& Wallerstein, 1991; Billig, et al., 1988; Reeves, 1983; Taguieff, 2005; van Dijk, 1993), we found that a variety of opposing principles, including both elements of tolerance and intolerance, were present within an overall position of tolerance. In line with Leach's (2005) critique of the conceptualization of "new racism", this study also presents a further argument against the reification of this concept. Overt symbols of racism are routinely rejected by 
right-thinking citizens and institutions, but not their societal and moral implications. Denial and ambivalence are key means by which racism thrives in society.

Apart from a few exceptions, associations between Roma ethnicity and crime operated mostly through forms of indirectness such as suggestions or innuendos. Through the use of three specific frames (policing, education, policy), policymakers ambivalently combined the recognition of the need for systemic policy based solutions, and inter-ethnic collaboration, with problematic suggestions about Roma predisposition toward law-breaking necessitated individual reforms. Interestingly, no such assumptions were held of non-Roma people engaged in anti-Roma violence. The conspicuous absence of any commentary related to prevention measures concerning anti-Roma prejudice and hate crimes towards Roma people places, perhaps unfairly, the onus on Roma people themselves, whilst divesting responsibility for challenging exclusionary public discourses.

The language used in the strategy documents to associate Roma with undesired behaviours, identity or values gradually changed over time, reflecting political and cultural changes in the Romanian socio-political context. With the implementation of the first strategy (Guvernul Romaniei - HG 430/2001.), the Romanian Government was answering the European Commission's requirements to improve the situation of Roma people, in order to join the European Union. Subsequent strategies were also answers to the European Commission's standards for Roma inclusion in EU member states (for a review of Roma inclusion policies across EU member states see: Cace et al., 2014). The language of the texts became increasingly subtler in the display of prejudicial and stereotypical views about Roma people. With each new strategy document ethnic blame was being inconspicuously couched more fully in the language of modern racism, making it harder to spot, and also harder to challenge. 
This paper has shown how, perhaps inadvertently, documents of the state with an explicit progressive agenda that aligns with EU strategic goals on social inclusion can display, and reproduce, marked ambivalence toward Roma people, common sense, and subtle racist ideas, when proposing systemic and policy-based solutions to the problem of ethnic disparity.

Awareness of this tendency can be used to further mobilize research on ways of combating subtle and common-sense forms of racism in contexts driven by an active interest in furthering tolerance and equality between groups. An explicit, yet uncritical progressive agenda can continue to reproduce a public imaginary in which Roma people are excised from the domain of moral acceptability and can have pernicious as well as subtler, long term, consequences. Roma people continue to be seen as the new face of marginality (and poverty) that occasions moral-political dilemmas even for the most liberal-leaning of policymakers. On the one hand, the situation of Roma people is deplored, yet on the other hand, it is recognized as very difficult to change and blamed on the individual. Well-intentioned policymakers strive to remove barriers and fight inequality, by giving priority to eliminating societal ills over ensuring everyday respect for some of the more vulnerable members of society. Understanding the less noticeable, ambivalent, manifestations of subtle forms of racism, places one in a much better position to understand the social and ideological ramifications of inclusion and exclusion as a product of progressive currents in modern democratic society.

\section{Acknowledgements}

The authors would like to thank the two anonymous reviewers and the editor of this journal for their helpful comments on earlier drafts of this paper. 


\section{References}

Akrami, N., Ekehammer, B., \& Araya, T. (2000). Classical and modern racial prejudice; A study of attitudes toward immigrants in Sweden. European Journal of Social Pcyhology, 30, 521-532.

Allport, G. W. (1954). The nature of prejudice. Reading MA: Addison-Wesley.

Anthisas, F. (1998). The limits of ethnic diversity. Patterns of prejudice, 32(4), 5-20.

Anttonen, R. (2008). Trust formation and experiences of prejudice and discrimination of Roma entrepreneurs in Finland. Journal of Enterprising Communities: People and Places in the Global Economy, 2(2), 124-139.

Augoustinos, M., \& Every, D. (2007). The language of 'race' and prejudice: A discourse of denial, reason, and liberal-practical politics. Journal of Language and Social Psychology, 26(2), 123-141.

Augoustinos, M., Tuffin, K., \& Every, D. (2005). New racism, meritocracy and individualism: Constraining affirmative action in education. Discourse \& Society, 16, $315-378$

Austin, J. (1961). How to do things with words. London: Oxford University Press.

Balch, A., Balabanova, E., \& Trandafiroiu, R. (2014). A Europe of rights and values? Public debates on Sarkozy's Roma affair in France, Bulgaria and Romania. Journal of Ethnic and Migration Studies, 40(8), 1154-1174.

Balibar, E. \& Wallerstein, I.; (1991). Race, Nation, Class. Ambiguous Identities. London: Verso.

Barker, M. (1981). The new racism. London: Junction Books. 
Billig, M. (1996) Arguing and Thinking: A Rhetorical Approach to Social Psychology (2nd edition), Cambridge: Cambridge University Press

Billig, M., Condor, S., Edwards, D., Gane, M., Middleton, D., \& Radley, A. (1988). Ideological Dilemmas. London: Sage.

Bobo, L. D.; Charles, C. Z.; Krysan, M.; Simmons, A. (2012). The real record on racial attitudes. In Marsdsen (ed.) Social Trends in American Life: Findings from the General Social Survey since 1972 (pp. 38-83). Princeton: Princeton University Press.

Bunescu, I. (2007). EU Eastern enlargement "Conditionality" of minority protection as a political oportunity for Romanian Roma. In-Spire: Journal of Law, Politics and Societies, 1-23. Retrieved September 5, 2015, from https://inspirejournal.files.wordpress.com/2011/12/bunescu01_romanian_roma.pdf

Cace, S., Neagu, G., Rat, C., \& Ivasiuc, A. (2014). Politici de incluziune a romilor in statele membre ale Uniunii Europene. Bucuresti: Institutul European din Romania.

Condor, S. (1988). 'Race stereotypes`and racial discourse. Text: An interdisciplinary journal for the study of discourse, 8(1-2), 69-89.

Dixon, J., Levine, M., Reicher, S., and Durrheim, K. (2012) 'Beyond prejudice: Are negative evaluations the problem and is getting us to like one another more the solution?', Behavioral and Brain Sciences, 35: 1-56.

Duminica, G., \& Ivasiuc, A. (2013). Romii din Romania. De la tap ispasitor la motor de dezvoltare. Bucuresti: Agentia Impreuna.

Duncan, S. S. (1977). The housing questions and the structure of the housing market. Journal of Social Policy, 6(4), 385-412. 
European Commision. (2018). Roma integration in the United Kingdom. Retrieved

November 30, 2018, from European Commision and its priorities:

https://ec.europa.eu/info/sites/info/files/roma_uk_strategy_en.pdf

European Commission. (2011). Communication from the Commission to the European

Parliament, The Council, The European Economic and Social Committee and the

Committee of the Regions. A EU Framework for the National Integration Strategies

up to 2020. Brussels: European Commission.

European Roma Rights Centre. (2001). State of Impunity: Human Rights and Roma in Romania. Budapest: Country Reports Series. ERRC.

European Union Agency for Fundamental Rights \& UNPD. (2012). The situation of Roma in 11 EU Member States. Survey results at a glance. Luxembourg: European Union Agency for Fundamental Rights.

Figgou, L., \& Condor, S. (2006). Irrational categorization, natural intolerance and reasonable discrimination: Lay representations of prejudice and racism. British Journal of Social Psychology, 45, 219-243.

Fraser, A. (1992) The Gypsies, Oxford: Blackwell.

Fremon, D. K. (2000). The Jim Crow Laws and Racism in United States History. Berkeley Heights: Enslow Publishers.

Gandy, O. H., Kopp, K., Hands, T., Frazer, K., \& Philips, D. (1997). Race and Risk: Factors affecting the framing of stories about inequality, discrimination and just plain bad luck. Public opinion Quarterly, 61, 158-182. 
Gilliam, F. (2006). The architecture of a new racial discourse: A FrameWorks message memo. Retrieved February 15, 2018, from http://www.frameworksinstitute.org/assets/files/PDF_race/message_memo_race.pdf

Goffman, E. (1974). Frame Analysis. Cambridge, Mass.;: Harvard University Press.

Guvernul Romaniei - HG 1.221/2011. (2012, April 4). Lege 5. Retrieved May 8, 2016, from The Governmental Decision 1.221/2011 for the aproval of the Romanian Government Strategy for the inclusion of the Romanian Citizens belonging to the Roma minority for the period of 2012-2020: http://lege5.ro/en/Gratuit/gi4dmmzuhe/anexa-lahotararea-guvernului-nr-1221-2011-pentru-aprobarea-strategiei-guvernului-romanieide-incluziune-a-cetatenilor-romani-apartinand-minoritatii-romilor-pentru-perioada2012-2020-din-14122011

Guvernul Romaniei - HG 18/2015. (2015, January 21). Lege5. Retrieved May 8, 2016, from Decizia nr 18/2015 pentru aprobarea Guvernului Romaniei a strategiei pentru incluziune a cetatenilor romani apartinand minoritatii rome pentru perioada 20142020: http://lege5.ro/en/Gratuit/guytsnzsha/hotararea-nr-18-2015-pentru-aprobareastrategiei-guvernului-romaniei-de-incluziune-a-cetatenilor-romani-apartinandminoritatii-rome-pentru-perioada-2015-2020

Guvernul Romaniei - HG 430/2001. (2001, May 5). Decision no 430/2001 regarding the aproval of the Governmental Strategy for the improvement of Roma situation. Retrieved May 8, 2015, from Lege5: Lege5: http://lege5.ro/Gratuit/gi4timjx/hotararea-nr-430-2001-privind-aprobarea-strategieiguvernului-romaniei-de-imbunatatire-a-situatiei-romilor 
Hammarberg, T. (2018). The shameul history of anti-Gypsyism is forgotten - and repeated. Retrieved December 3, 2018, from Council of Europe - Commisioner for Human Rights. Viewpoints: https://archive.is/20120630002157/www.coe.int/t/commissioner/Viewpoints/080818_ en.asp

Horovath, I., \& Nastasa, L. (1992). Rom sau Tigan? Dilemele unui etnonim in spatiul romanesc. Cluj: Editura Institutului pentru Studierea Problemelor Minoritatilor Nationale; Fundatia Soros Romania.

Institutul National de Statistica. (2011). Recensamantul populatiei si locuintelor. Institutul National de Statistica. doi:http://www.recensamantromania.ro/noutati/volumul-iipopulatia-stabila-rezidenta-structura-etnica-si-confesionala/

Iyengar, S. (1991). Is anybody responsible? How television frames political issues. Chicago: University of Chicago Press.

Jayaratne, T. E.; Gelman, S. A., Feldbaum, M.; Sheldon, J. (2009). The Perennial Debate: Nature, Nurture, or Choice? Black and White Americans' Explanations for Individual Differences. Review of General Psychology, 13 (1), 24-33.

Katz, P. A., \& Taylor, D. A. (1988). Eliminating racism. Profiles in controversy. New York: Plenum.

Kinder, D. R., \& Sanders, L. M. (1996). Divided by color: Racial politics and democratic ideals. Chicago: University of Chicago Press.

Kinder, D. R., \& Sears, D. O. (1981). Prejudice and politics: Symbolic racism versus racial threats to the good life. Journal of Personality and Social Psychology, 40, 414-431. 
Kuypers, J. A., \& D'Angelo, P. (2010). Doing News Framing Analysis. Empirical and theoretical perspectives. New York: Rutledge.

Lasticova, B., \& Findor, A. (2016). Developing explicit measures of stereotypes and antiRoma prejudice in Slovakia: Conceptual and methodological challenges. Human Affairs, 26, 233-252.

Leach, C. W. (2005). Against the notion of 'new racism'. Journal of Community \& Applied Social Psychology, 15, 432-445.

Marihno, C., \& Billig, M. (2013). The CDS-PP and the Portuguese Parliament's annual celebration of the 1974 Revolution: ambivalence and avoidance in the construction of the fascist past. In R. Wodak \& J. E. Richardson (eds.) Analysing Fascist Discourse: European fascism in talk and text (pp. 146-162). London: Routledge.

Maurer, K. L., Park, B., \& Rothbart, M. (1995). Subtyping versus subgrouping processes in stereotype representation. Journal of Personality and Social Psychology, 69, 812-824.

McConahay, J. B. (1986). Modern racism, ambivalence and modern racism scale. In J. F. Dovidio, \& S. L. Gaertner, Prejudice, Discrimination and Racism (pp. 91-125). New York: Academic Press.

McConahay, J. B., \& Hough, J. C. (1976). Symbolic racism. Journal of social issues, 32(2), $23-45$.

McConahay, J. B., Hardee, B. B., \& Batts, V. (1981). Has racism declined in America? It depends on who is asking and what is asked. Journal of Conflict Resolution, 25, 563579. 
Mendelberg, T. (2001). The race card: Campaign strategy, implicit messages, and the norm of equality. Princeton: Princeton University Press.

Mullard, C. (1985). Race, class, and ideology. London: Routledge \& Kegan Paul.

Nicolae, V. (2006). Words that kill. Index on Censorship, 35(1), 137-141.

Okely, J. (1983) The Traveller-Gypsies, Cambridge: Cambridge University Press.

Partidul Comunist Roman. (1978). Informare privind unele probleme pe care le ridica populatia de tigani din tara noastra. Retrieved October 17, 2016, from https://www.militiaspirituala.ro/fileadmin/documente/doc.pdf.poze.documente_inedit e/tiganiada-_1978.pdf

Pettigrew, T. F., \& Meertens, R. W. (1995). Subtle and blatant prejudice in Western Europe. European Journal of Social Psychology, 25, 57-75.

Pettigrew, T. F., \& Meertens, R. W. (2001). In defence of the subtle prejudice concept: A retort. European Journal of Social Psychology, 299-309.

Potter, J., \& Wetherell, M. (1987). Discourse and Social Psychology. London: Sage.

Romanian Government - HG 430/2001. (2001, May 5). Decision no 430/2001 regarding the aproval of the Governmental Strategy for the improvement of Roma situation. Retrieved May 8, 2015, from Lege5: http://lege5.ro/Gratuit/gi4timjx/hotararea-nr430-2001-privind-aprobarea-strategiei-guvernului-romaniei-de-imbunatatire-asituatiei-romilor

Ryan, W. (1971). Blaming the Victim. New York: Random House. 
Sacks, H. (1984). Notes on Methodology. In J. M. Atkinson, \& J. Heritage, Structures of Social Action: Studies in Conversation Analysis. Cambridge: Cambridge University Press.

Sears, D. O. (1988). Symbolic racism. In P. A. Katz \& D. A. Taylor (Eds.), Perspectives in social psychology. Eliminating racism: Profiles in controversy (pp. 53-84). New York: Plenum Press.

Sniderman, P. M., \& Tetlock, P. E. (1986). Symbolic racism: Problems of motive attribution in political analysis. Journal of Social Issues, 42, 129-150.

Snow, D. A., Rochford, E. B., Worden, S. K., \& Denford, R. D. (1986). Frame aligment processes, micromobilization and movement participation. American Sociological Review, 51(4), 546-581.

Strauss, A., \& Corbin, J. (1997). Grounded Theory in Practice. London: Sage Publications.

Tarnovschi, D. (2012). Situatia romilor in Romania, 2011: Intre incluziune si migratie. Raport de tara. Constanta: Editura Dobrogea.

The National Commission for Demographics; The Committee for the Problems of the Popular Councils; The Ministry of Study and Education; The Ministry of Work; The Ministry of Health; The Internal Ministry; The General Prosecutor for the SRR. (1977). Studiu privind situatia social-economica a populatiei de tigani din tara noastra. Bucharest. Retrieved October 17, 2016, from https://www.militiaspirituala.ro/fileadmin/documente/doc.pdf.poze.documente_inedit e/tiganiada-_1977.pdf 
Tileagă, C. (2007). Ideologies of moral exclusion: A critical discursive reframing of depersonalization, delegitimization and dehumanization. British Journal of Social Psychology, 46(4), 717-737.

Tileagă, C. (2015) The nature of prejudice: Society, discrimination and moral exclusion. London: Routledge.

United Nations Development Programme. (2012). Roma education in comparative perspective. Findings from the UNDP/World Bank/EC Regional Roma survey. UNPD. Retrieved November 30, 2018, from http://issuu.com/undp_in_europe_cis/docs/education_web van Dijk, T. A. (1992). Discourse and the denial of racism. Discourse \& Society, 3(1), 87118.

van Dijk, T. A. (1993). Elite discourse and racism. London: Sage Publication.

Varadi, L. (2014). Youths trapped in prejudice: Hungarian adolescents' attitudes towards the Roma. Wiesbaden: Springer.

Verloo, M. (2005). Mainstreaming gender equality in Europe: A critical frame analysis approach. The Greek Review of Social Research, 117(B), 11-34.

Verloo, M. (2007). Multiple meanings of gender equality. A critical frame analysis of gender policies in Europe. Budapest: Central European University Press.

Villano, P., Fontanella, L. S., \& Di Donato, M. (2017). Stereotyping Roma people in Italy: IRT models for ambivalent prejudice measurement. International Journal of Intercultural Relations, 57, 30-41. 
Wetherell, M. (2012). The prejudice problematic. In J. Dixon, \& M. Levine, Beyond

Prejudice. Extending the social psychology of conflict, inequality and social change

(pp. 158-178). Cambridge: Cambridge University Press.

Wetherell, M., \& Potter, J. (1992). Mapping the language of racism: Discourse and the

legitimation of exploitation. Hemel Hemstead: Harvester Wheatsheaf.

World Bank. (2014). Studiu de diagnosticare si consultanta pentru politicile de sprijinire a

incluziunii romilor din Romania. Washington : World Bank.

Zamfir, E., \& Zamfir, C. (1993). Tiganii intre ignorare si ingrijorare. Bucuresti: Editura

Alternative.

\footnotetext{
${ }^{1}$ In this study race was understood as a socially constructed perception of differences such as skin color, eye shape, hair texture or other facial features. Ethnicity was defined as perceived variations in language, clothing, or other behaviors between groups which were attributed to culture.
}

${ }^{2}$ Three observations can be made regarding the attitudinal shift, and the ambivalence displayed by white people. Firstly, biological attributions did not disappear. Research has found that biological, race based explanations continued to be offered by some study participants for perceived differences in mathematical ability, intelligence, and predilection for violence (Jayaratne, et al., 2009). Secondly, the "new" cultural attributions which established whiteness as norm to which any other racial or ethnic groups should aspire can be traced back to European colonial rule (Pehrson \& Leach, 2012). Thirdly, trait-based explanations, although usually offered by white people, were also found among black people. For example, one study found that a lack of motivation was suggested as a reason for social and economic disparities by $44 \%$ of black respondents (Samson \& Bobo, 2014).

3 "Jim Crow" laws were passed in the late 1800s and they separated black people from white people in public transportation, hospitals, schools, orphanages, funeral homes and cemeteries. For an overview of the Jim Crow laws and racism in US History see Fremon (2000).

${ }^{4}$ Drawing a parallel between racial and gender power relations, Wetherell (2012) suggested that although one group can be guilty of oppressing another, it would be too simplistic to maintain that the personal weaknesses of the oppressors was the main cause of the problem. Granting that soul-searching and self-critique can certainly make a difference for the individual man or woman, or even particular institutions, patriarchal or racist practices cannot be overthrown without a radical change in social organization, a change that would generate different economic and social patterns.

${ }^{5}$ During the International Roma Congress, which took place in London in 1971, Roma elites proposed abandoning the common usage of exonyms as Tigani, Tsiganes, Zigeuner, Gitanos, and Gypsy, by arguing that these terms were derogatory. Instead Roma, also spelled Rroma, was proposed as an alternative endonym. Up until the Congress, international Roma organizations were known as "Gypsy Organizations"; "Organizatii tiganesti"; "Communauté Mondiale Gitane" or "Comité International Tsigane". A resolution was passed and the endonim Roma was registered by international bodies including the United Nations, UNESCO, and the Human Rights Commission. In Romania, Roma people continued to be labelled as tigani (Gypsy) until Article 3 of Law $33 / 1995$ mentioned that any person belonging to a national minority has the right to freely choose how she/he is treated and how she/he desires to be ethnically named. Also, the endonim Roma was officially imposed by the European Commission in 1999, when it was concluded that the term "Gypsy" and the variants of Tsigan were considered by many Roma to be pejorative, and was abandoned as a result (Horovath \& Nastasa, 1992). 
${ }^{6}$ Sinti refers to the members of the Roma ethnic minority living in Western and Central Europe. Roma refers to the members living in Eastern and Southeastern Europe.

Table 1: Comparative size of documents

\begin{tabular}{|c|c|c|c|c|}
\hline Document & Date & $\begin{array}{l}\text { Number of } \\
\text { pages }\end{array}$ & $\begin{array}{l}\text { Number of } \\
\text { words }\end{array}$ & $\begin{array}{l}\text { Number of } \\
\text { paragraphs }\end{array}$ \\
\hline $\begin{array}{l}\text { Strategy } 1 \mathrm{a}-4 \text { years } \\
\text { plan }(2001-2004)\end{array}$ & 2001 & 19 & 7244 & 228 \\
\hline $\begin{array}{l}\text { Strategy } 1 b-2 \text { years } \\
\text { plan }(2006-2008)\end{array}$ & 2006 & 28 & 8456 & 124 \\
\hline $\begin{array}{l}\text { Strategy } 2-8 \text { years plan } \\
(2012-2020)\end{array}$ & 2011 & 67 & 20164 & 495 \\
\hline $\begin{array}{l}\text { Strategy } 3-5 \text { years plan } \\
(2015-2020)\end{array}$ & 2015 & 117 & 36186 & 761 \\
\hline
\end{tabular}

